\title{
MENINGKATKAN PENGETAHUAN MASYARAKAT MELALUI PROGRAM PENYULUHAN SOKRATIK-DEMONSTRASI
}

\author{
Erika $^{1}$, Nur Asni Art ${ }^{2}$, Rahma Fridayana Fitri ${ }^{3}$ \\ ${ }^{1,2}$ Sekolah Tinggi Ilmu Kesehatan Indah Medan, Medan, Indonesia \\ ${ }^{3}$ Universitas Sumatera Utara, Medan, Indonesia \\ Email: 12pasariburika@gmail.com, ${ }^{2}$ asniartinur@gmail.com, ${ }^{3}$ rahmafridayana@gmail.com
}

\begin{abstract}
ABSTRAK
Pandemi Covid-19 telah memicu terjadinya anxiety (gangguan kecemasan), yang diakibatkan oleh munculnya rasa takut akan tertular Covid-19, sehingga mempengaruhi berbagai aspek kehidupan masyarakat. Indonesia merupakan salah satu negara dengan tingkat infeksi COVID-19 yang tinggi dikarenakan adanya berbagai masalah. Masalah-masalah ini sangat umum di kalangan penduduk. Salah satunya berkaitan dengan kesadaran masyarakat, kecemasan dan kurangnya pengetahuan masyarakat tentang ancaman pandemi Covid-19. Hal ini terlihat dari kurangnya kesadaran masyarakat akan isu menjaga kebersihan dan perlindungan terhadap Covid19. Meski sudah diimbau oleh kepala desa dan staf untuk mengikuti protokol kesehatan, masyarakat yang keluar rumah tanpa menggunakan masker masih banyak ditemui di tempat-tempat umum. Ini adalah tugas penting untuk menekan penyebaran kasus positif COVID-19. Dalam situasi ini, perlu untuk meningkatkan kesadaran masyarakat untuk mencegah infeksi COVID-19. Tujuan dari penulisan artikel ini adalah untuk menilai efektivitas metode konseling empiris Socrates. Metode penyuluhan dilakukan pada 30 orang di desa Lestaridadi untuk dipublikasikan di jurnal.
\end{abstract}

Kata Kunci: Metode, Penyuluhan , Covid-19, Sokratik-Demonstrasi, Masyarakat

\section{ABSTRACT}

The Covid-19 pandemic has affected various aspects of people's lives, triggering anxiety (anxiety disorders) for fear of contracting Covid-19. Indonesia is one of the countries with a high number of Covid-19 transmissions due to various problems. These problems are prevalent among the people. One of them is the lack of public awareness, concern, and knowledge about the threat of the Covid-19 pandemic. This can be seen in the lack of public awareness in maintaining cleanliness and personal protection from Covid-19. People who do not wear masks when they leave the house are still often found in various public environments, even though the Village Head and his staff have been advised to comply with health protocols. This is a crucial concern to reduce the transmission of positive cases of Covid-19. In these circumstances, it is necessary to increase public knowledge so as not to be infected by Covid-19. This paper aims to determine the effectiveness of the demonstration-Socratic counseling method. This counseling method was carried out to 30 people from the Lestaridadi Village community, aiming for journal publication as an output.

Keywords: Covid-19, Method, Counseling, Socratic-Demonstration, Society

\section{PENDAHULUAN}

Situasi yang diakibatkan oleh pandemi COVID-19 (pandemi global) mempengaruhi berbagai aspek kehidupan masyarakat sehingga menimbulkan kecemasan (anxiety disorder) karena takut terinfeksi COVID-19. Indonesia merupakan salah satu negara dengan angka penularan kasus Covid-19 yang tinggi disebabkan berbagai permasalahan (Satuan Gugus Tugas Covid 19, 2021). Permasalahan-permasalahan tersebut khususnya banyak ditemukan di 
kalangan masyarakat. Salah satunya berkaitan dengan kurangnya kesadaran, minat, dan pengetahuan masyarakat tentang ancaman pandemi Covid-19. Hal ini terlihat dari kurangnya kesadaran masyarakat akan isu menjaga kebersihan dan perlindungan terhadap Covid19. Meski sudah diimbau oleh Kepala Desa Lestaridadi dan jajarannya untuk mengikuti protokol kesehatan, masyarakat yang tidak menggunakan masker saat keluar rumah masih banyak ditemui di berbagai tempat umum.. Hal ini penting menjadi perhatian untuk menekan angka penularan kasus positif Covid-19 (Keputusan Menteri Kesehatan Republik Indonesia, 2020). Dalam situasi ini, perlu untuk meningkatkan kesadaran masyarakat untuk mencegah infeksi COVID-19. Tujuan artikel ini adalah memberikan solusi untuk memberikan pengetahuan dan pemahaman kepada masyarakat tentang pencegahan infeksi COVID-19 melalui Metode Penyuluhan Sokratik-Demonstrasi. Metode cakupan ini diterapkan pada 30 orang di desa Lestaridadi.

\section{Metode}

\section{Metode Penyuluhan Sokratik-Demonstrasi}

Metode sokratik dilakukan dengan komunikasi dua arah antara pemberi dan penerima informasi(Ilyas \& Putri, 2012; Rizkika et al., 2014). Penerima informasi diberikan kesempatan mengemukakan pendapatnya dan dua orang atau lebih dengan latar belakang yang berbeda, bekerja sama saling memberikan keterangan, dan ikut serta menyatakan pendapat (Simons et al., 2000). Salah satu metode Socratik yang cocok adalah demonstrasi. Metode demonstrasi mendemonstrasikan bagaimana melakukan suatu tindakan atau prosedur atau menyajikan materi dengan memberikan penjelasan lisan, gambar, dan ilustrasi.. Tujuan metode demonstrasi, yaitu mengajar seseorang bagaimana melakukan suatu tindakan seperti melakukan tindakan pencegahan Covid-19 seperti mencuci tangan memakai masker, dan menjaga jarak. Kelebihan metode ini adalah dapat dijelaskan suatu prosedur secara visual, sehingga mudah dimengerti dan masyarakat dapat mencoba pengetahuan yang diterimanya(Erika \& Fitri, 2021).

Tahapan dalam pelaksanaan penyuluhan dengan metode sokratik-demonsrasi untuk meningkatkan pengetahuan masyarakat dalam pencegahan penularan Covid-19. Dalam melakukan penyuluhan kesehatan, maka penyuluh yang baik harus melakukan penyuluhan sesuai dengan langkah - langkah dalam penyuluhan kesehatan masyarakat sebagai berikut (Devi Pramita Sari \& Nabila Sholihah 'Atiqoh, 2020; SK MENKES RI, 2002; Zahrotunnimah, 2020):

1. Pengkajian kebutuhan kesehatan masyarakat.

2. Identifikasi masalah kesehatan masyarakat.

3. Memprioritaskan masalah yang ditangani terutama edukasi kesehatan melalui penyuluhan kepada masyarakat.

4. Tetapkan rencana penuyuluhan

a. Penetapan tujuan

b. Penentuan target sasaran

c. Penyusunan materi penyuluhan 

d. Menentukan metoda yang tepat
e. Pilih jenis alat peraga yang diperlukan
f. Penentuan kriteria evaluasi.

\section{Pelaksanaan penyuluhan}

6. Penilaian hasil penyuluhan

7. Tindak lanjut dari penyuluhan

Penyuluhan kesehatan masyarakat melalui ceramah dan demonstrasi.

\section{Penyuluhan melalui Ceramah \\ Persiapan}
a. Menentukan tujuan.
b. Menenukan Sasaran
c. Mempersiapkan Materi.
d. Topik yang dikemukakan hanya satu masalah sesuai dengan kebutuhan sasaran.
e. Mempersiapkan alat peraga yang sesuai dengan topic.
f. Menentukan waktu dan tempat.
g. Mempersiapkan bahan bacaan bila diperlukan.

\section{Pelaksanaan}
a. Memperkenalkan diri.
b. Jabarkan tujuan penyuluhan.
c. Jelaskan pokok permasalahan yang akan dibahas.
d. Menyampaikan materi penyuluhan dengan artikulasi yang jelas dan bahasa yang mudah dimengerti.
e. Pandangan penyuluh merata ke seluruh peserta penyuluhan.
f. Selipkan humor untuk mencairkan suasana.
g. Alat peraga digunakan demi memudahkan materi untuk dipahami dan bawakan secara santai.
h. Beri kesempatan pada peserta untuk bertanya hal-hal yang kurang mereka mengerti.
i. Jawablah pertanyaan dengan jelas dan menyakinkan.
j. Beri simpulan di akhir ceramah.

\section{Penilaian}

Penyuluhan dinilai berhasil apabila:
a. Ada respons berupa pertanyaan.
b. Adanya usulan meneruskan kegiatan ceramah.
c. Perhatian peserta yang besar terhadap materi ceramah.
d. Peserta dapat menjawab pertanyaan ketika ditanya mengenai materi.

\section{Demonstrasi}

\section{Persiapan}
a. Menetapkan tujuan.
b. Menentukan materi.
c. Menentukan target sesuai latar belakangnya.
d. Menentukan perkiraan waktu demonstrasi.
e. Menentukan alat yang akan digunakan. 
f. Menyesuaikan materi dengan demostrasi yang akan dilaksanakan

g. Mengecek persiapan secara keseluruhan dan peralatan yang sudah dipersiapkan.

\section{Pelaksanaan}

a. Memberi penjelasan tujuan demonstrasi.

b. Membangun keakraban dengan bersikap yang ramah, sopan, dan memikat.

c. Penjelasan materi demonstrasi dengan menggunakan ilustrasi melalui alat-alat yang dipakai secara teliti dan benar.

d. Memberi penekanan pada materi penting dengan cara mengulang-ulang agar peserta benar-benar mengerti dan mudah mengingatnya.

e. Memberi kesempatan kepada beberapa peserta untuk mendemonstrasikannya seperti apa yang telah diperagakan oleh penceramah.

f. Menyediakan sesi tanya-jawab.

\section{Penilaian}

Demonstrasi berhasil bila:

a. Ada banyak pertanyaan mengenai materi dan prosedur yang didemonstrasikan dan jawaban memuaskan peserta.

b. Peserta meminta dilakukan demonstrasi serupa atau yang lain.

c. Peserta puas akan demonstrasi yang dilaksanakan.

d. Apa yang didemonstrasikan dapat diaplikasikan pada kehidupan sehari-hari

\section{Hasil dan Pembahasan}

Hasil yang dicapai melalui kegiatan pengabdian kepada masyarakat yang dilaksanakan di Desa Lestaridadi, Kecamatan Pegajahan, Kabupaten Serdang Bedagai, dalam bentuk hasil kegiatan pada setiap pelaksanaan dalam beberapa tahap, yaitu:

\section{Hasil}

Di dalam tahap pelaksanaan dilakukan 4 kegiatan secara bertahap yaitu :

\section{Tahap pembentukan}

Tahap pembentukan merupakan tahap perkenalan, tahap melibatkan diri ke dalam kehidupan peserta penyuluhan. Pada tahap ini semua anggota memperkenalkan diri satu sama lain dan mengungkapkan tujuan dan harapan yang ingin dicapai baik oleh masingmasing, sebagian maupun seluruh anggota. Kegiatan yang dilakukan pada tahap ini adalah sebagai berikut :
a. Penjelasan pengertian dan tujuan dari penyuluhan
b. Penjelasan cara penyuluhan yang dilakukan
c. Melaksanakan acara perkenalan antara peserta penyuluhan
d. Menciptakan permainan penghangatan keakraban

\section{Tahap Peralihan}

Tahap peralihan adalah tahapan untuk mengalihkan kegiatan awal peserta penyuluhan ke kegiatan berikutnya yang lebih terarah pada pencapaian tujuan penyuluhan. Kegiatan dalam tahap ini adalah sebagai berikut : 

a. Tim penyuluh memberi kuesioner kepada masing-masing peserta.
b. Peserta mengisi kuesioner yang sudah dibagikan.
c. Peserta mengumpulkan kertas kuesioner untuk di evaluasi oleh tim penyuluh.
d. Kegiatan selingan

Tabel 1 Distribusi Frekuensi Berdasarkan Jenis Kelamin

\begin{tabular}{|c|c|c|c|c|}
\hline & Frequency & Percent & $\begin{array}{c}\text { Valid } \\
\text { Percent }\end{array}$ & Cumulative Percent \\
\hline Laki-laki & 17 & 56.7 & 56.7 & 56.7 \\
\hline Perempuan & 13 & 43.3 & 43.3 & 100.0 \\
\hline Total & 30 & 100.0 & 100.0 & \\
\hline
\end{tabular}

Sumber: Peserta Penyuluhan Desa Lestaridadi (2021)

Tabel 1 menunjukkan bahwa jumlah peserta penyuluhan adalah 30 orang yang terdiri dari Laki-laki 17 orang (56.7\%), dan perempuan berjumlah 13 orang $(43.3 \%)$.

\section{Tahap Kegiatan}

Tahap kegiatan adalah tahap ketiga yang merupakan inti dari kegiatan penyuluhan. Kegiatan dalam tahap ini adalah sebagai berikut :
a. Tim penyuluh menjelaskaan cara-cara pencegahan covid-19.
b. Tanya jawab antara peserta dengan tim penyuluh
c. Dilanjutkan dengan demonstrasi cara pencegahan covid-19, memakai masker, mencuci tangan, menjaga kebersihan diri dan keluarga.
d. Kegiatan selingan
e. Peserta membahas masing-masing topik secara mendalam dan tuntas
f. Tim penyuluh membagikan kuesioner untuk diisi oleh peserta
g. Kuesioner dikumpulkan untuk di evaluasi

\section{Tahap Pengakhiran}

Tahap pegakhiran adalah tahap penutup dalam kegiatan penyuluhan. Dalam tahap ini tim penyuluh melakukan kegiatan seperti :

a. Tim penyuluh menyampaikan bahwa kegiatan akan segera berakhir

b. Meminta peserta memberikan kesan dan pesannya

c. Membahas kegiatan lanjutan

d. Mengemukakan pesan dan harapan 


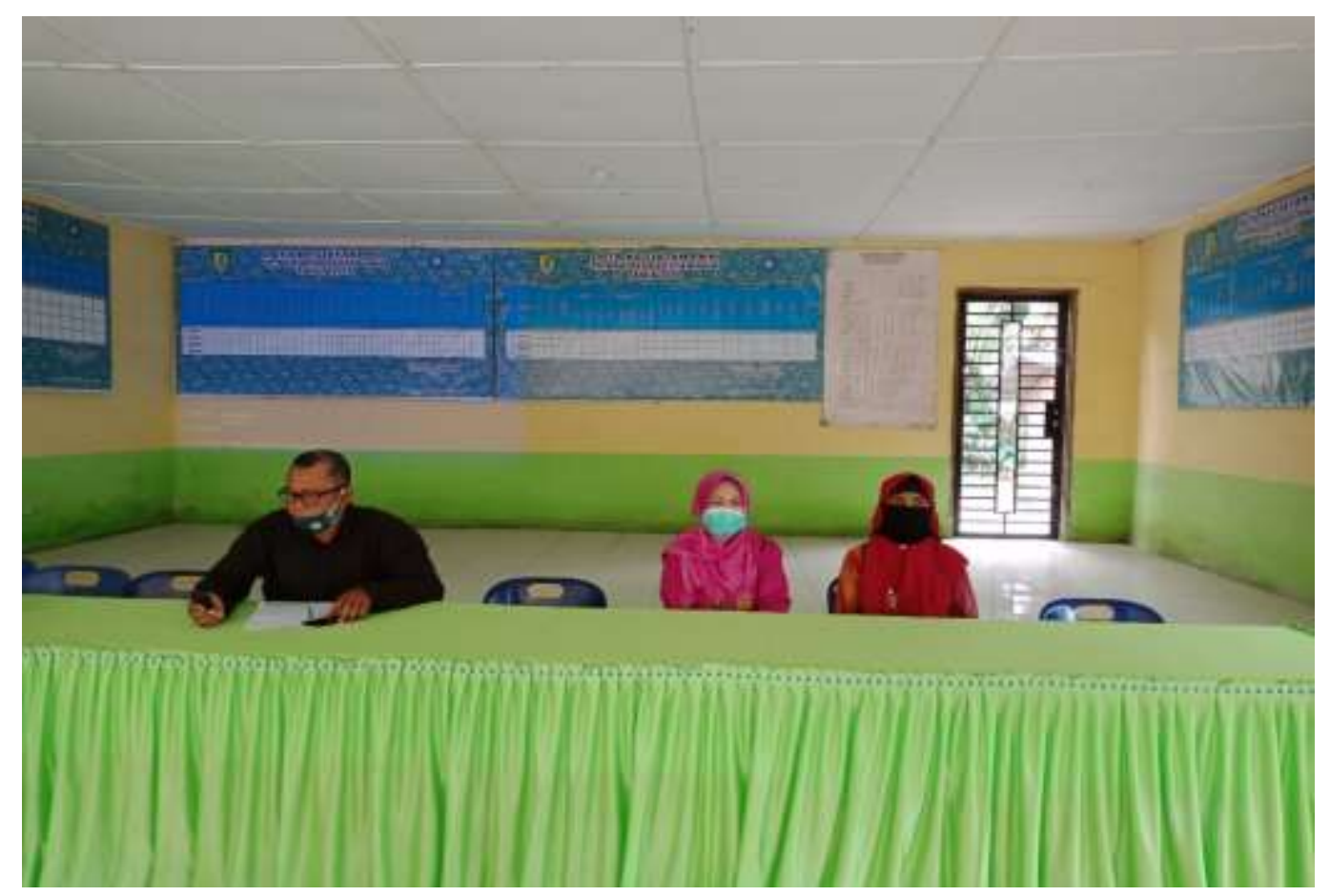

Gambar 1 Tim Pengabdi mengusulkan susunan acara kepada Kepala Desa Lestaridadi

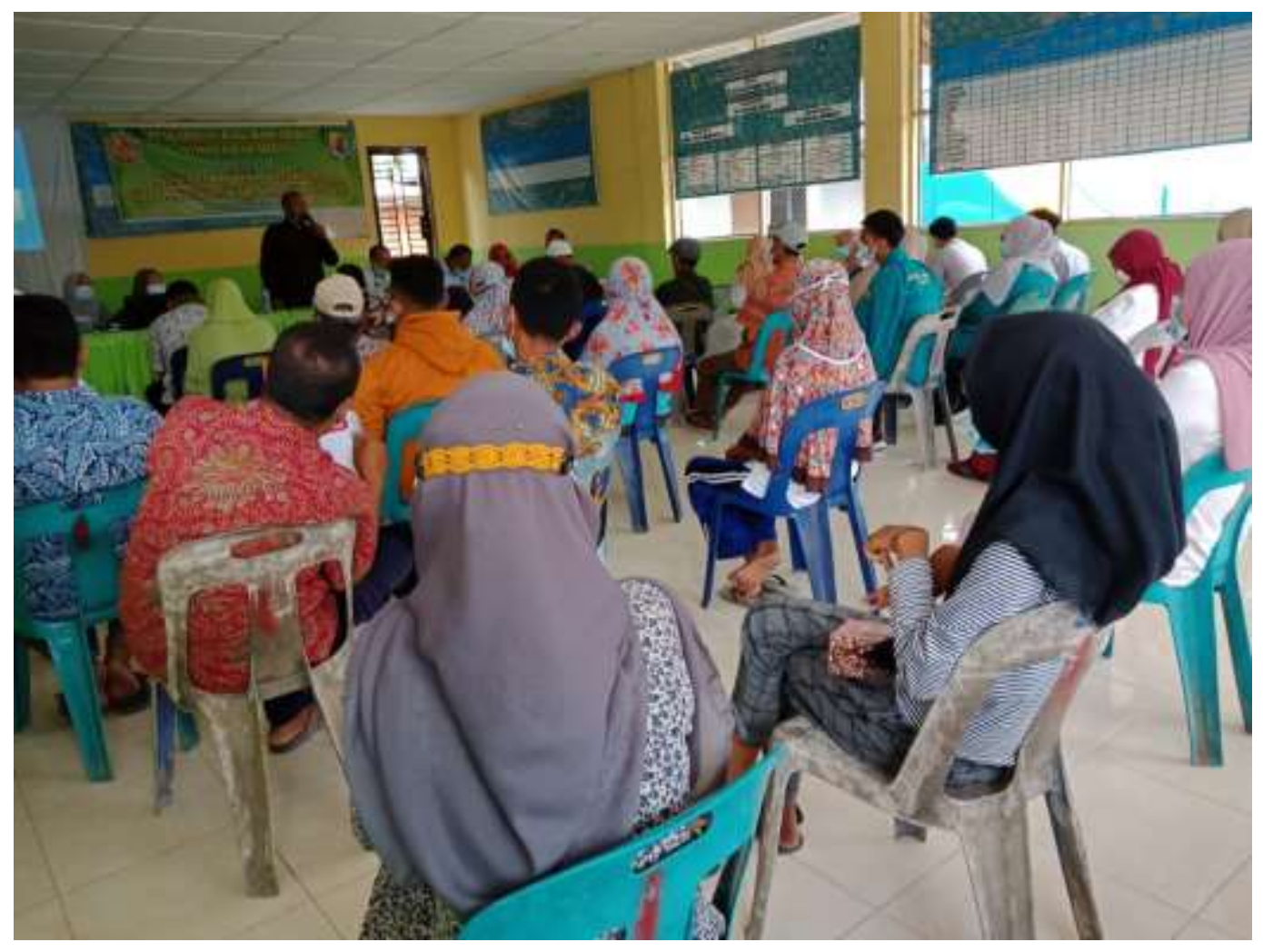

Gambar 2 Kata Sambutan oleh Kepala Desa sekaligus pembukaan acara penyuluhan 
Pelaksanaan pengabdian masyarakat yang dilaksanakan di Desa Lestaridadi Kecamatan Pegajahan Kabupaten Serdang Bedagai telah berjalan dengan baik. Hal ini terlihat dari apresiasi peserta penyuluhan dan perangkat Desa Lestaridadi untuk mengikuti kegiatan, terbukti dari kehadiran peserta untuk mengikuti kegiatan ini. Kepala Desa beserta staf di lingkungan Desa Lestaridadi menyambut dengan antusias kegiatan pengabdian masyarakat ini. Dari hasil pelaksanaan pengabdian masyarakat yang dilaksanakan di Desa lestaridadi terbukti bahwa progran penyuluhan belum berjalan dengan baik dikarenakan masyarakat yang sibuk dengan bertani, sehingga tidak ada waktu untuk mendengarkan penyuluhan, sehingga penyuluhan ini dilakukan sore sampai malam hari agar pesertanya mendapat waktu luang.

Oleh karena itu diharapkan kepada pemerintah dan lembaga Lembaga lainnya agar lebih mengembangkan pelaksanaan penyuluhaan pencegahan covid-19 di Desa Lestaridadi, sehingga dapat meningkatkan keterampilan masyarakat dalam melakukan pencegahan covid-19.

Tim Pengabdi pada Masyarakat melakukan pengolahan data dengan tujuan untuk mengetahui pengetahuan masyarakat tentang pencegahan covid-19 sebelum dilakukan penyuluhan dengan menggunakan statistic deskriptif dalam menjelaskan hasil pra tes, dan dilanjutkan melakukan pengolahan data untuk mengetahui sejauh mana pengetahuan masyarakat sudah meningkat tentang pencegahan covid-19 setelah dilakukan penyuluhan (pos tes) dengan menggunakan statistic deskriptif, dapat dijelaskan sebagai berikut:

Tabel 2. Hasil Descriptive Statistics Pre Tes dan Pos Tes

\begin{tabular}{lr|r|r|r|r}
\hline & N & Minimum & Maximum & Mean & \multicolumn{1}{c}{$\begin{array}{c}\text { Std. } \\
\text { Deviation }\end{array}$} \\
\hline Pre Tes & 30 & 28 & 59 & 40.93 & 6.690 \\
\hline Pos Tes & 30 & 72 & 97 & 86.00 & 6.513 \\
\hline Valid N (listwise) & 30 & & & & \\
\hline
\end{tabular}

Dari hasil deskriptif statistik pre tes dan pos tes nilai minimum pada pre tes adalah 28 dan maksimum adalah 59 dengan rata-rata 40.93. namun pada pos tes yang dicapai minimum 72 dan maksimum 97 dengan rata-rata 86.00

Penyuluhan ini dilakukan untuk mengetahui peningkatan pengetahuan masyarakat setelah dilakukan penyuluhan dengan metode Sokratik-Demonstrasi. Pada penyuluhan ini, Tim Pengabdi hanya mengambil 30 peserta karena pada masa pandemic tidak boleh mengumpulkan orang dengan jumlah besar. Walaupun jumlah peserta hanya sedikit, diharapkan peserta yang sudah mengikuti penyuluhan dapat menyampaikan informasi tersebut kepada keluarga, tetangga, dan masyarakat lainnya.

Dari hasil deskrriptif statistic pre tes dan pos tes nilai minimum pada pre tes adalah 28 dan maksimum adalah 59 dengan rata-rata 40,93. namun pada pos tes yang dicapai minimum 72 dan maksimum 97 dengan rata-rata 86,00. 
Dalam konsep pendidikan kesehatan lebih ditekankan pada upaya perbaikan perilaku subjek agar pengetahuan subjek konseling sesuai dengan apa yang diharapkan darinya, terutama dalam hal kognitif yang sehat. Karena ada instruktur kebersihan, konsultasi selanjutnya akan dilakukan sesuai program yang dijadwalkan. Kegiatan pelengkap berguna untuk memperluas pengetahuan dan kemampuan melalui metode pembelajaran praktis atau instruksi untuk mengubah perilaku individu dalam individu, kelompok, atau masyarakat..

Metode penyuluhan yang umum digunakan adalah metode didaktik (one way method) dan metode sokratik (two way method). Pada metode didaktik pemberi informasi cenderung aktif sedangkan penerima informasi sebagai sasaran tidak diberi kesempatan mengemukakan pendapat. Metode sokratik dilakukan dengan komunikasi dua arah antara pemberi dan penerima informasi. Memberi kesempatan kepada orang yang diberikan informasi untuk mengungkapkan pendapatnya, dan berpartisipasi dalam memberikan informasi dan mengemukakan pendapat oleh dua orang atau lebih dari latar belakang yang berbeda. Salah satu metode Socrates yang cocok adalah demonstrasi. Metode demonstrasi mendemonstrasikan bagaimana melakukan suatu tindakan atau prosedur atau menyajikan materi dengan memberikan penjelasan lisan, gambar, dan ilustrasi.. Tujuan metode demonstrasi, yaitu mengajar seseorang bagaimana melakukan suatu tindakan seperti melakukan tindakan pencegahan Covid-19 seperti mencuci tangan memakai masker, dan menjaga jarak (Rambe, 2019)(Purnomo, 2016). Kelebihan metode ini adalah dapat dijelaskan suatu prosedur secara visual, sehingga mudah dimengerti dan masyarakat dapat mencoba pengetahuan yang diterimanya.

\section{Kesimpulan}

Dari hasil Analisa yang dilakukan masih banyak masyarakat yang memiliki pengetahuan kurang, diharapkan bagi peserta yang sudah mengikuti penyuluhan ini agar menyebarkan pengetahuannya kepada masyarakat di Desa Lestaridadi. Dari data dan fakta yang telah dipaparkan diatas maka penulis dapat menyimpulkan bahwa rata-rata nilai pretest adalah 40.93 dan nilai rata-rata posttest adalah 86, sehingga dari hasil ini dapat disimpulkan bahwa melalui metode penyuluhan sokratik-demonstrasi dapat meningkatkan pengetahuan dalam hal ini dapat meningkatkan pengetahuan peserta penyuluhan dengan metode sokratikdemonstrasi

\section{Saran}

Berdasarkan hasil pengolahan data dan kesimpulan diatas maka Tim Pengabdi bermaksud memberikan saran yang mudah-mudahan dapat bermanfaat bagi Lembaga maupun Tim penyuluh yang selanjutnya.

Dari hasil observasi masih banyak masyarakat belum terjangkau oleh tim pengabdi karena keterbatasan waktu, pengabdi mengharapkan pada tim pengabdi selanjutnya untuk melakukan penyuluhan dengan hal yang sama untuk masyarakat yang belum terjangkau, dan mengkaji lebih banyak sumber maupun referensi yang terkait dengan metode penyuluhan. 


\section{Ucapan Terima Kasih}

Puja dan puji penulis sampaikan kehadirat Allah SWT atas berkat dan rahmat-Nya yang telah melindungi dan membimbing sehingga penulis dapat menyelesaikan penyusunan pengabdian pada masyarakat ini yang berjudul: "meningkatkan Pengetahuan Masyarakat melalui Program Penyuluhan Sokratik-Demonstrasi.

Penyuluhan ini tidak akan terlaksana tanpa bantuan dan dukungan dari berbagai pihak. Untuk itu dengan segala kerendahan hati, pada kesempatan ini penulis menucapkan terimakasih kepada:

1. Dr. Apt. Samran, M.Si selaku Ketua Sekolah Tinggi Ilmu Kesehatan Indah Medan

2. Muhammad Kasim selaku Kepala Desa Lestaridadi

3. Semua teman sejawat yang telah memberikan bantuan atas terselenggaranya pengabdian pada masyarakat ini.

4. Reviewer yang membantu untuk terbitnya artikel ini

5. Semua pihak yang terkait yang belum disebutkan pada tulisan ini.

\section{Referensi}

Devi Pramita Sari, \& Nabila Sholihah 'Atiqoh. (2020). Hubungan Antara Pengetahuan Masyarakat Dengan Kepatuhan Penggunaan Masker Sebagai Upaya Pencegahan Penyakit Covid-19 Di Ngronggah. Infokes: Jurnal Ilmiah Rekam Medis Dan Informatika Kesehatan, 10(1), 52-55. https://doi.org/10.47701/infokes.v10i1.850

Erika, \& Fitri, R. F. (2021). Efektifitas Penggunaan Metode Penyuluhan SokratikDemonstrasi Dalam Peningkatan Pengetahuan Masyarakat Dalam Pencegahan Penularan COVID-19. Exelent Midwifery Journal, 4(1), 83-90. http://www.unp.ac.id/node?page $=7$

Ilyas, M., \& Putri, I. N. (2012). Efek penyuluhan metode demonstrasi menyikat gigi terhadap penurunan indeks plak gigi pada murid sekolah dasar Effect of demonstration method counseling on brushing teeth to the decreasing of plaque value of elementary school students. Journal of Dentomaxillofacial Science, 11(2), 91. https://doi.org/10.15562/jdmfs.v11i2.302

Keputusan Menteri Kesehatan Republik Indonesia. (2020). Keputusan Menteri Kesehatan Republik Indonesia Nomor HK.01.07/MenKes/413/2020 Tentang Pedoman Pencegahan dan Pengendalian Corona Virus Disease 2019 (Covid-19). In MenKes/413/2020 (Vol. 2019).

Purnomo, M. (2016). Pencapaian Standar Pelayanan Gawat Darurat Di Rsu Habibullah Berdasarkan Standar Pelayanan Minimal Rumah Sakit Tahun 2014. The 3rd University Research Colloquium 2016, 144-158.

Rambe, R. P. (2019). A Multimodal Analysis of English Courses's Brochures Advertisement in Medan. 140705154.

RI, D. (2002). Keputusan Menkes RI No. 228/MENKES/SK/III/2014 Tentang Pedoman 
Penyusunan Standar Pelayanan Minimal Rumah Sakit yang Wajib Dilaksanakan Daerah.

Rizkika, N., Baehaqi, M., \& Putranto, R. R. (2014). Efektivitas Menyikat Gigi Dengan Metode Bass Dan Horizontal Terhadap Perubahan Indeks Plak Pada Anak Tunagrahita. ODONTO : Dental Journal, 1(1), 29. https://doi.org/10.30659/odj.1.1.29-33

Satuan Gugus Tugas Covid 19. [Internet]. covid19.go.id. 2021 [cited 11 August 2021]. Available from: https://covid19.go.id/(Issue August). (2021). https://covid19.go.id/

Simons, D., Baker, P., Jones, B., Kidd, E. A. M., \& Beighton, D. (2000). An evaluation of an oral health training programme for carers of the elderly in residential homes. British Dental Journal, 188(4), 206-210. https://doi.org/10.1038/sj.bdj.4800432

Zahrotunnimah, Z. (2020). Langkah taktis pemerintah daerah dalam pencegahan penyebaran virus Corona Covid-19 di Indonesia. Jurnal Sosial Dan Budaya Syar-I, 7(3), 247-260. http://www.akrabjuara.com/index.php/akrabjuara/article/view/919 